\title{
Sexual Orientation and Gender Identity Claims of Asylum in Germany
}

Intersectional legal, social and methodological challenges

Dr Nina Held

INTRODUCTION ${ }^{1}$

“"flee, but make sure you wear pink"” (Gartner, 2016, p. 12)

How do people who are seeking asylum on the basis of sexual orientation and gender identity (PSASOGI $^{2}$ in Europe prove their claim? What do they need to do to get their claim accepted? Does someone claiming asylum on grounds of SOGI in Germany have a higher chance of their claim being accepted than someone making a claim on grounds of SOGI in the UK or Italy? What are not only the legal but also the social experiences of PSASOGI in these countries? How can these experiences be improved, and how can European asylum systems treat SOGI asylum claims more fairly?

These are some of the questions the research project SOGICA - Sexual Orientation and Gender Identity Claims of Asylum: A Human Rights Challenge tries to answer. SOGICA is a four-year European project funded by the European Research Council (ERC). It is a comparative study that investigates how asylum claims based on SOGI are treated in the UK, Germany and Italy, and at European Union (EU) and Council of Europe (CoE) levels. The number of SOGI asylum claims and acceptance rates in Europe is unknown, as most EU member states do not record the grounds for claiming asylum. The European study Fleeing Homophobia (Jansen and Spijkerboer, 2011) indicated that there is no consistency as to how the EU member states treat SOGI claims. Since Fleeing Homophobia was published, the

\footnotetext{
${ }^{1}$ This contribution has been produced within the context of the project 'Sexual Orientation and Gender Identity Claims of Asylum: A European human rights challenge-SOGICA'. This project has received funding from the European Research Council (ERC) under the European Union's Horizon 2020 research and innovation programme (grant agreement No 677693). The author of this book chapter is one of the three postdoctoral researchers working on the project and is responsible for the German case study (the other researchers are Dr Moira Dustin, who is responsible for the UK case study and Dr Carmelo Danisi, who is responsible for the Italian case study). The project is led by Prof Nuno Ferreira. For more information on the project, please visit www.sogica.org.

${ }^{2}$ The idea for the term PSASOGI came after a discussion with a Friend of the SOGICA project - Aderonke Apata, who told us that in her opinion 'people who are seeking asylum' should be used rather than 'asylum seekers', 'to bring the people out'. The term asylum seeker is often used in fixed ways/ as a fixed identity, without acknowledging the agency and diversity of the people who are seeking asylum.
} 
Court of Justice of the European Union (CJEU) has made two important decisions on SOGI claims (see below). However, as I will discuss below with the example of Germany, the implementation of these decisions into domestic law is not clear-cut.

The SOGICA project looks at how the social and legal experiences of PSASOGI's 'refugeeness' are not only shaped by sexual orientation and gender identity, but also by the intersections with other social categories such as gender, 'race', religion and social class. By drawing on the first phase of the project and focusing on the German case study, this chapter explores what intersectional legal and social challenges PSASOGI face. The chapter therefore aims to contribute to the small, but growing, literature that links intersectionality and asylum (Firth and Mauthe, 2013), or uses the concept of intersectionality for the exploration of the lives of PSASOGI (Baillot et al. 2012; Berger 2009; Epstein and Carrillo 2014; Lewis 2014; Morgan 2006). But first, let me discuss SOGICA's methodology and some ethical implications of studying the lives of PSASOGI.

\section{SOGICA's METHODOLOGY}

The SOGICA projected started in September 2016 and continues until August 2020. In these four years, the project consists of different phases: 1. delineating the project's methodology and theoretical frameworks, in particular how human rights, feminist and queer studies and the concept of intersectionality can be used as particular lenses for the analysis of SOGI asylum claims; 2. conducting fieldwork in Germany, Italy, the UK and EU and on Council of Europe (CoE) levels; 3. analysing the data, writing up the results and producing detailed policy recommendations.

This chapter was written during the first and beginning of the second phase of the project, i.e. during the process of writing, data had been collected but not yet analysed. Hence, in this chapter I only draw on material collected during the first phase of the project.

The main research questions that SOGICA seeks to address are:

- How have European countries incorporated human rights violations related to sexual orientation and gender identity into their asylum policies?

- How do these violations constitute, and how are they seen to constitute, causes of asylum requests? 
- How are sexual orientation and gender identity related asylum claims legally adjudicated at domestic, EU and Council of Europe levels?

- Does the legal adjudication of SOGI related asylum claims influence claimants' identity and integration in the host society? If so, how?

- How can the domestic, EU and Council of Europe legal frameworks adjudicate sexual orientation and gender identity related asylum claims more fairly?

SOGICA adapts an inter-disciplinary (socio-legal), comparative and intersectional approach to address these questions and explore the social and legal experiences of PSASOGI. The project's interdisciplinary approach uses legal and sociological theoretical frameworks and methods. Employing a wide range of quantitative and qualitative methods, socio-legal approaches look at the social factors involved, the social impact of law and practice (McConville and Chui, 2007, p. 20). For our project, these approaches are especially useful for exploring the relationship between sexuality, gender (identity) and the law, and their intersections with other social relations of power. The comparative approach seeks to analyse how the EU harmonised framework is disposed of within distinct jurisdictional, procedural, cultural and political contexts. By focusing on Germany, Italy and the UK, we aim to explore good and bad practices, as well as some distinct trends that may guide asylum decision and policy-making. Whilst intersectionality is key for this research as a theoretical concept, it also guides our methodology. By applying intersectionality as methodology, we follow Matsuda's approach to 'ask the other question' (Matsuda, 1991). That means that, during the data collection and analysis, when we explore accounts of sexuality we ask 'where is gender here?'; in accounts on gender we ask 'where is “race" here?'; and so on. This is vital for exploring the socio-legal experiences of SOGI claimants and guides how we develop the different methods we use for the data collection across the three case study countries.

\section{Methods}

In order to achieve an analysis that offers both breadth and an in-depth understanding, a mixed-methods approach is used.

Data is collected using the following methods: 
- 140 semi-structured interviews with PCASOGI, policy-makers, decision-makers, members of the judiciary, legal representatives, and NGO activists, plus interviews with policy-makers at European level;

- 12 focus-groups with PCASOGI;

- 30 non-participant contextual observations of court hearings;

- Questionnaires (self-completion)/ online-surveys for PCASOGI and a range of other stakeholders;

- Documentary analysis of international, European and domestic case-law, policy documents, NGO reports, case files, etc.

The interviews last between 60 and 90 minutes. SOGI asylum seekers and refugees are asked questions about their social and legal experiences regarding their asylum claims. Focusgroups offer an opportunity for sharing and comparing views in a way that individual interviews do not. Questions in the focus-groups concentrate on asylum-seekers' opinions about the asylum process for SOGI claimants and support services available. The interviews with policy-makers, decision-makers, members of the judiciary, legal representatives and NGO activists explore these actors' experiences with SOGI asylum claims and provide particular perspectives on good and bad experience of practice in the individual contexts. The interview and focus group transcripts are analysed using a qualitative data analysis software (NVivo).

It is important to recognise the interactive nature of data collection; for instance, an interview is always a joint production of accounts (Rapley, 2007). We follow the approach Rapley (2007, p. 26, original emphasis) calls "'engaged, active or collaborative" interviewing'. It is vital to respect participants' privacy by not asking too personal questions. Furthermore, allowing dialogue, and being truthful about what the study can achieve and what the limitations are, are essential for building trusting relationships (Krause, 2017).

As Krause (2017) suggests, a human rights approach to research is especially important when conducting research on refugees who have experienced human rights violations. Participants need to be able to speak about the issues that are important to them. Krause thus argues that '[c]rucially, when participants can speak out about issues that are relevant for them, they are not treated as “data sources" but as persons.' (Krause, 2017, 20) This issue is also important from an intersectional perspective. For instance, even though our research focuses on sexuality, gender identity and refugeeness as social categories of identity, 
we also ask participants questions addressing other categories such as 'race' and religion, and keep the interviews loosely structured as to allow participants to integrate references to intersections with other categories.

We aim to include a range of perspectives in our project. Therefore, when recruiting participants, we look for a diverse sample in terms of sexual orientation, sex, gender identity, country of origin and other factors such as religion, age and social class. Important for that is also that we provide information about the project in different languages. In order to reach people widely, we provide translations of the project flyer, confidentiality and consent forms not only in English, German and Italic but also in Arabic, French, Turkish, Urdu and Farsi.

In order to be able to base findings on a heterogeneous sample, it is important to not only rely on gatekeepers but to use other recruitment strategies too. Gatekeepers often fear that their clients are 'too vulnerable' and traumatised to participate in research projects and therefore they close the door to researchers (as the SOGICA team has also experienced). In addition, NGOs might only refer participants who they see as the 'ideal' sample (e.g. for the reputation of the organisation) (United Nations High Commissioner for Refugees, 2003, p. 14). ${ }^{3}$ Hence, for recruiting participants, we use a wide range of means such as publishing the call for participants in newsletters, mailing lists, relevant publications, and on social media.

\section{Ethical implications}

It might be said that fulfilling ethical standards is important for any project; however, due to the particular position in PSA find themselves, considering ethical implications when conducting research with this group of participants is particularly important. ${ }^{4}$ PSA are in some sense 'vulnerable' because of their legal status but also because they are likely to have experienced some traumatic events. Depression, post-traumatic stress disorder (PTSD) and anxiety are common in the refugee population. Therefore, the retelling of traumatic events can have a considerable impact on research participants' mental health. If it was their SOGI that caused PSASOGI harm, then talking about these aspects of themselves, and their experience in this regard, might be re-traumatising. However, as Stevenson and Willott

\footnotetext{
${ }^{3}$ When gatekeepers are involved, it is important to make sure that potential research participants understand that the service provision they receive from that organisation is not affected by their decision to participate in the research or not (see Clark-Kazak, 2017, p.12).

${ }^{4}$ Approval from the University of Sussex' Ethics Committee has been obtained in the project's first year (certificate of approval for Ethical Review ER/NH285/1).
} 
(2006) point out, we might not always have the right understanding of what topics will be sensitive for a participant. There might be other intersecting parts of PSASOGI's identities that are more difficult to talk about and foresee.

It is important not to cause psychological harm by asking questions in an insensitive way; or probing too much about experiences that seem to cause distress to the interviewee (Krause, 2017). ${ }^{5}$ Participants need to be made aware of the fact that the interview could potentially be re-traumatising for them. It is crucial to take extra time to explain in writing and verbally the aims of the study and what participation involves. Researchers need to allow enough time for potential participants to ask questions, and think about and reflect whether they want to participate, and decide whether they feel emotionally and mentally prepared to share and discuss their experiences on the subject-matter.

Whilst there is a risk that interviews can re-traumatise participants, the potential therapeutic effect of telling their story in a safe environment has also been pointed out (Harrell-Bond and Voutira, 2007). Often refugees are keen to participate in research to make their voices heard, and help improving the lives of refugees, if not directly for themselves, then for future refugees, as it has also been expressed by some of our participants (see also Venturi, 2017). ${ }^{6}$

However, the issue of 'vulnerability' is complex. Whilst PSA might in some sense be vulnerable because of their legal status, not all refugees are vulnerable; some are immensely resourceful, and might not consider themselves vulnerable (Stevenson and Willott, 2006). Taking intersectionality seriously means that when assessing vulnerability, we 'need to consider both the individual circumstances of each research participant, rather than see them as a homogenous group.' (Stevenson and Willott, 2006, p. 383) By focusing on hardship and using victimising notions, people seeking asylum are often portrayed as having similar experiences, and being vulnerable (Krause, 2017). But the label of vulnerability can be patronising. Instead of homogenising PSASOGI as a 'vulnerable group', intersecting identities of each person need to be taken into account when assessing vulnerability. It is important to also highlight asylum seekers and refugees' agency. For instance, many are themselves involved in establishing networks, support groups, and other forms of refugee

\footnotetext{
${ }^{5}$ This can also cause psychological harm to researchers. For instance, hearing stories of violence, rape, etc. can be difficult for researchers and cause distress (Krause, 2017, p. 4).

${ }^{6}$ This was also my experience when I volunteered for the Lesbian Immigration Support Group (LISG) in Manchester (UK). LISG (http://lesbianimmigrationsupportgroup.blogspot.de/) is a voluntary-led support group for bisexual and lesbian asylum seekers and refugees. I volunteered for the group from 2009-2016. During this time, we had been approached by many researchers and some members took part in several research projects as they appreciated having their voices heard, and wanted to make a difference to asylum seekers' lives and raise awareness of the situation of LGBTQI refugees.
} 
activism. ${ }^{7}$ In that respect, whilst it might be crucial to anonymise data to avoid risks, it is also important to grant participants the autonomy to decide for themselves whether they want their accounts to be anonymised or not (Clark-Kazak, 2017; Krause, 2017). In any case, research participants need to be given the right to withdraw their informed consent at any stage of the research.

It has been highlighted that the uniqueness of the refugee experience brings high levels of distrust with it - because of mistreatment in countries of origin, but also mistreatment during the asylum process (United Nations High Commissioner for Refugees, 2003). PSASOGI in particular will have had experiences of not being able to trust people and 'be out' with regard to their SOGI. This will be exaggerated by the power differentials between researchers and researched and the fact that researchers often treat research participants as solely 'data source' and not as active subjects with rights, dignity and agency (Krause, 2017). ${ }^{8}$ The asylum system disempowers PSASOGI, and often PSASOGI have internalised disempowering messages. Traditional approaches to research can make PSA and refugees feel exploited (Cochrane, 2015).

The three SOGICA researchers who conduct interviews with PSASOGI are cisgendered (one male, two female) white academics with considerable social, economic and cultural capital. Hence, power inequalities between us and the participants of the study are likely to exist on grounds of 'refugeeness', gender, 'race', socio-economic situation and political rights status. In the interactive process of data collection power differentials (real or assumed) need to be addressed, whilst acknowledging that power is relative and exists in relationships, i.e., it can shift and change. Hence, it is important to not only consider the intersecting identities of participants, but also those of the researchers.

In our project, we aim to do research with refugees instead of for or on refugees (United Nations High Commissioner for Refugees, 2003, p. 14, original emphasis) and to

\footnotetext{
${ }^{7}$ For instance, in Germany between 2012 and 2014, a large number of refugees actively protested against their living conditions and engaged in spatial politics, showing acts of resistance in refugee camps and accommodations. These protests included organising demonstrations, raising awareness of the living conditions of asylum seekers, and occupying several places in Berlin, such as the Oranienplatz, the Gerhard-Hauptmann-Schule, a roof of a hostel, a church, the TV tower at Alexanderplatz, and the floor of the German Trade Unions in Berlin (to gain support from trade unions). These protests gained national and international media attention, providing a visible platform for their demands (Bhimji, 2016).

${ }^{8}$ In my work at LISG, for instance, it happened all too often that after access to participants had been gained, trust won, and women been interviewed, researchers did not ever contact us again. Such conduct contributes to PSASOGI's frustration and mistrust of researchers, but it also takes the opportunity away from them to use research findings for their own causes (Krause, 2017, Mackenzie, 2007).
} 
work collaboratively as much as possible. ${ }^{9}$ Crucial here is that we keep in contact with all participants throughout the project and offer emotional and practical support, wherever we can. We will provide updates on the project in different stages of the project and send participants the full report and the summary of our findings when the project is finished, when they will also be invited to our final conference. Whilst we are aware that power differentials are not likely to diminish, we aim to conduct research that brings reciprocal benefits and establishes 'ethical relationships between researchers and participants that are responsive to the needs, concerns and values of participants.' (Mackenzie et al., 2007, p. 307)

\section{THE GERMAN CASE STUDY}

For SOGICA's comparative study, Germany is interesting for several reasons: it has taken a leading role in what is often referred to as Europe's 'refugee crisis', processing more asylum claims than any of the other 27 EU Member states, having received 1.3 million refugees between 2015 and 2017 alone. ${ }^{10}$ But Angela Merkel's 'generous' asylum politics have been met with an increase in anti-immigrant sentiments, and a far-right party playing a key role in German politics for the first time since the Nazi movement in the 1930s. In the 2017 general election, the political party Alternative for Germany (Alternative fuer Deutschland) gained $12.6 \%$ of the votes and 94 seats in the Bundestag (German Federal Parliament). ${ }^{11}$ Like all asylum seekers and refugees in Germany, PSASOGI find themselves in a country full of contradictions: a generous border politic and welcome culture ('Willkommenskultur'), but also a not so generous asylum process and often inadequate living conditions, combined with an increasingly hostile environment. As I will show, this contradictory culture affects PSASOGI, whose asylum seeker status intersects with gender, 'race', sexuality and religion in complex ways that shape their experience.

\footnotetext{
${ }^{9}$ Some of the ways we try to do that: we have established a 5-member Advisory Board consisting of stakeholders, including two refugee women. In the spirit of knowledge exchange, we are keen to collaborate with research participants and stakeholders throughout the project, and we are trying to make this a genuinely two-way process so that we are also giving something in return. All researchers are engaged with local NGOs. We have established a database of resources, which will hopefully be useful for PCASOGI, practitioners and researchers alike. We give presentations and workshops and offer training and other support to PCASOGI, refugee and migrant organisations. Furthermore, we will disseminate findings widely to academic and non-academic audiences and make sure that we reach PCASOGI through networks and social media.

10 http://www.dw.com/en/more-asylum-requests-processed-in-germany-than-rest-of-eu-combined-reports/a-36984339? , access date: 5 June 2017.

${ }^{11}$ https://www.bundeswahlleiter.de/info/presse/mitteilungen/bundestagswahl-2017/34_17_endgueltiges_ergebnis.html, access date 15 October 2017.
} 
Germany is also interesting to look at because of its legal system that falls within the civil law model. In contrast to the UK's common law and adversarial justice system, for instance, where the evidence gathering burden is shared between decision-maker and asylumseeker but ultimately lies on the claimant, Germany adopts an inquisitorial system, i.e. the decision-maker takes the lead in gathering evidence. As a report by AIDA $(2015,41)$ states: '[t]he BAMF [Das Bundesamt für Migration und Flüchtlinge/ Federal Office for Migration and Refugees] is generally obliged to clarify the facts of the case and to compile the necessary evidence.' This, however, can lead to harmful practices by the BAMF, for instance when it tries to get information directly from the applicant's social context in his/her country of origin. In a shocking example that was referred to in a court case in 2007, the BAMF gathered information from the foreign office with regard to the alleged homosexuality of a man from Nigeria. The foreign office questioned his sister about her brother's sexual relationships and made further inquiries in Lagos, where he used to live, and concluded that his sexuality could not be confirmed ${ }^{12}$. Here then, potential harm had been caused by outing the claimant in his country of origin, thus exposing him to danger if he has to return.

In addition, the country reports produced by the German Foreign Office usually only have a small section on SOGI and are inadequate. These sections often focus solely on homosexuality and marginalise transgender issues (Huebner, 2016, 247). Because of the inquisitorial nature, also the judges are actively involved in investigating the facts of the case (which can be highly intimidating for the claimant) rather than just playing the role of a referee during the hearing, as it is the case in adversarial systems (such as the UK). ${ }^{13}$ Thus, German courts are required to gain relevant evidence of their own initiative and are not bound by previous decisions. SOGICA aims to explore whether the nature of law systems as inquisitorial or adversarial makes a difference to SOGI claims. It also investigates how German's federal structure might impact on the legal experiences and social welfare of PSASOGI. $^{14}$

\section{SOGI claims in Germany}

\footnotetext{
${ }^{12}$ VG München, Urteil vom 30.1.2007, M 21 K 04.51404, see Hempel 2014, p. 53.

${ }^{13}$ The differences between the legal system in Germany and the UK might also impact on the implementation of gender guidelines for instance. In the UK, the judiciary has more agency because of the precedent case system whilst in Germany the courts should only interpret the German codification system. This might make it more possible for 'norm advocates' to influence the judiciary in the UK than this is the case in Germany (see Markard 2011).

${ }^{14}$ The administration of asylum is not homogeneous across Germany. The federal structure of the political system influences how asylum policies are implemented, and differences in the implementation seem to exist between the 16 federal states (especially with regard to living conditions).
} 
As there are no official figures available on the protection reasons, we do not know how many asylum claims are SOGI-related in Germany. Whilst the Fleeing Homophobia report (Jansen and Spijkerboer, 2011) refers to a relatively low number of SOGI claims in 2011, this will have changed in recent years due to the general increase in asylum claims. It is estimated that there are 3,500 PSASOGI in Berlin alone. ${ }^{15}$ However, it is noteworthy that not all LGBTQI people who claim asylum will base their asylum claim on their SOGI as they might feel reluctant to 'out' themselves during the asylum procedure and might fear that friends and family find out about their sexual orientation (Kalkmann, 2010, p.4-6). Some will have fled due to reasons other than SOGI, and some might not know that claiming asylum on grounds of SOGI is a possibility. ${ }^{16}$

Asylum claims based on SOGI fall under Article 1A(2) of the 1951 Geneva Convention Relating to the Status of Refugees (the Refugee Convention), which defines a refugee as a person who

owing to well-founded fear of being persecuted for reasons of race, religion, nationality, membership of a particular social group or political opinion, is outside the country of his nationality and is unable or, owing to such fear, unwilling to avail himself of the protection of that country. ${ }^{17}$

Depending on the exact Refugee Convention ground on the basis of which one wishes to claim asylum, asylum claimants need to provide evidence of, for example, political activity, ethnicity and so on. In claims based on SOGI, claimants need to submit evidence of persecution, or fear of persecution, because of their SOGI, or perceived SOGI. In particular, claimants need to prove that they belong to a 'particular social group' (PSG), i.e. lesbian/bisexual/gay/transgender/intersex.

In Germany, however, the granting of refugee status on the Convention ground of PSG is a fairly recent phenomenon and has only gained significance since 2005, when Article

\footnotetext{
15 http://uk.reuters.com/article/us-germany-refugees-lgbt-idUKKCN0V02D8, access date 15 October 2017.

${ }^{16}$ Although the Asylum Act contains obligations to inform applicants of the asylum procedure, NGOs have criticised the fact that the leaflets handed out and the oral briefings provided are insufficient to adequately prepare claimants for their interview. In his German report for Fleeing Homophobia, Kalkmann (2010) outlined that claimants were not made aware of the fact that sexual orientation or gender identity are grounds for asylum.

${ }^{17}$ My emphasis.
} 
10 (paragraph 1) of the EU Qualification Directive 2004/83/EC $C^{18}$ was transposed into German law through the Residence Act, ${ }^{19}$ recognising claims of persecution on grounds of SOGI. ${ }^{20}$ Since then, the fear of persecution by non-state actors has also been accepted in refugee claims (Hempel, 2014; Kalkmann, 2010).

With a landmark decision of the Federal Administrative Court (Bundesverwaltungsgericht) $^{21}$ in 1988, persecution on grounds of sexual orientation started falling under 'asylerheblichen Merkmals' of the Constitution (hence related to political persecution), instead of the Refugee Convention's PSG as was the case in the UK, for instance. ${ }^{22}$ The Federal Administrative Court decided that, under specific circumstances, the persecution of homosexual men in Iran could be accepted as 'political persecution'. However, this judgment, which still stands today (in relation to constitutional asylum) was based on a problematic understanding of homosexuality. Considering when the decision was made, in some ways it was progressive, as it drew on an understanding of sexuality as not 'curable' (it was common during that time to believe that it could be cured), but as 'irreversible', 'inescapable' and 'fateful' (Huebner, 2016). However, the Court's decision pathologised homosexuals in other ways, namely as not being able to control their sexual urges ('triebhaft'). Moreover, criminalisation of same-sex sexual activities was not sufficient for granting asylum, and the courts specified that criminalisation was not a sufficient ground if such norms existed to protect 'public morality' (Kalkmann, 2010, Huebner, 2016). In the case of Iran, however, the courts found that the death penalty was a very harsh punishment and disproportional to keeping public morality. ${ }^{23}$

\footnotetext{
${ }^{18}$ Council Directive 2004/83/EC of 29 April 2004 on minimum standards for the qualification and status of third country nationals or stateless persons as refugees or as persons who otherwise need international protection and the content of the protection granted, OJ L 304, 30.9.2004, p. 12-23. In the meantime replaced with the recast Directive 2011/95/EU of the European Parliament and of the Council of 13 December, 2011 on standards for the qualification of third-country nationals or stateless persons as beneficiaries of international protection, for a uniform status for refugees or for persons eligible for subsidiary protection, and for the content of the protection granted, OJ L 337, 20.12.2011, p. 9-26.

${ }^{19} \mathrm{http}: / /$ www.gesetze-im-internet.de/englisch_aufenthg/index.html

${ }^{20}$ The right to asylum is enshrined in Art. 16a 1) Grundgesetz (GG, Germany's constitution), and implemented through 33 (1) of the Asylum Act (Asylgesetz - AsylG) and $\S 60$ (1) of the Residence Act (Aufenthaltsgesetz - AufenthG). In the two latter acts, the definition of a refugee according to the Refugee Convention has been incorporated literally into the national law. As Markard (2015) points out, although Article 16a GG refers specifically to 'political persecution', the German courts have assumed that this norm conforms to the Refugee Convention and therefore only used 16a GG to decide on asylum cases.

${ }^{21}$ BVerwGE, 15 March 1988, C 278.86.

${ }^{22}$ In contrast, in the UK already in 1999 has it been accepted that women, and lesbians and gay men can form a 'particular social group' (Shah and Islam v Secretary of State for the Home Department, House of Lords, 2 A.C. 629, 1999).

${ }^{23}$ Not to forget here is that West-Germany had also criminalised homosexuality for over 20 years and legalised it only in 1969 (it was decriminalised in East-Germany in 1968). Also in West-Germany, it was argued that these laws were in place to protect morality and decisions by the Federal Administrative Court contributed to holding this up. So, in this judgement the court might have tried to defend their own decision-making in the past (see Hempel, 2014, 47).
} 
This decision, on which many others have subsequently been based, made a distinction between homosexuals whose sexual orientation was 'irreversible' and those whose sexual orientation was only 'latent' (hence they could choose whether to be gay or not). For the latter, it implicitly denied one's right to live their sexual orientation openly, and forced them to live 'in the closet' (Markard, 2013, p.75). The consequence of this decision was that for years to come, courts based their decisions on an assessment of the 'intensity' of the irreversibility of homosexuality, and often commissioned medical and sexual 'scientific' reports to assess this (up to 2012, according to Hempel 2014, p.42). This led to rather obscure decisions in the administrative courts. For instance, in one case the court argued that the claimant's sexual desires were not 'abnormal' and compulsory, and therefore he would be able to suppress and compensate for these desires by masturbating. ${ }^{24}$

This case law of the Federal Administrative Court and the administrative courts became outdated, when persecution on grounds of gender identity and sexual orientation became recognised under the PSG requirement of the Refugee Convention. As the courts explain, it now does not matter whether the sexual identity of the claimant is so 'inescapable' to not be able to abstain from same-sexual activity ${ }^{25}$.

When establishing membership of PSG, the German Federal Office for Migration and Refugees and the courts in Germany have followed the cumulative approach according to the Qualification Directive, i.e. the claimant needs to demonstrate that they are member of a social group that has a distinct identity in their country of origin and share a fundamental characteristic with this group (see Hathaway and Foster, 2014, p.430). According to Wessels (2017), however, the Qualification Directive only triggered a conceptual change from an 'immutable' characteristic (such as race or nationality) to one that is so 'fundamental' human identity that it cannot be renounced (such as religion or political opinion). Hence, the courts still assess fear of persecution and whether it can be expected from someone to be discreet about their sexual identity and behaviour, based on whether the behaviour is 'indispensable' for the claimant's identity.

In Germany, as in most European countries, the existence of 'anti-homosexuality laws' is not sufficient to prove fear of persecution. Unfortunately, in 2013 also the CJEU ruled in $X, Y, Z^{26}$ that the mere existence of criminal laws punishing same-sex conduct was not enough proof of the existence of persecution. There are currently 73 countries (and 5

\footnotetext{
${ }^{24}$ VG Regensburg, U. v. 4.8.1998 (see Hempel, 2014, 48; Markard, 2013, 76).

${ }^{25}$ See, for instance, Administrative Court of Frankfurt/Oder 19.11.2015 - 4 K 1099/12.A.

${ }^{26}$ Joined Cases C-199/12, C-200/12 and C-201/12, X, Y and Z v Minister voor Immigratie, Integratie en Asiel, 7 November 2013, ECLI:EU:C:2013:720.
} 
entities) in the world (40\% of all countries) with legislation in place that criminalises samesex consensual acts between adults. ${ }^{27}$ These anti-homosexuality laws do not exist in isolation but are often linked to discrimination and intolerance in the society (Markard, 2013). Nonetheless, as Huebner $(2016,256)$ points out, in Germany refusals are often based on the reasoning that the existing laws are not used or that there is no knowledge that these laws are used, and there seems to be an increasing number of refusals based on such 'asylum relevance'. ${ }^{28}$

Overall, there seem to be discrepancies in the ways in which the BAMF and administrative courts deal with SOGI claims (Tometten, 2016). Case law does not always refer to the existence of a particular social group, or indeed any other Refugee Convention ground and there seems to be no common approach in the handling of these claims (Kalkmann, 2010; Huebner 2016). For instance, before the CJEU decision in $X, Y$ and $Z$ in 2013 (see below), it was quite common for courts to argue that the claimant would not face any persecution if he/she were to be discreet and did not live their sexuality openly in public. $^{29}$ However, other decisions exist, where the courts disagreed with the discretion reasoning and argued that it was unacceptable to ask a claimant to keep their sexuality secret. $^{30}$

In $X, Y$ and $Z$, the CJEU made it clear that homosexuals can fall under PSG for the purposes of the Refugee Convention under the Qualification Directive and that it is a human rights violation to ask applicants to be discreet about their sexuality. In December 2012, in anticipation of this judgment, in a letter to a Member of Parliament, Volker Beck, the BAMF confirmed that it had changed its decision-making and had abolished the discretion reasoning (Markard, 2013, p. 402). ${ }^{31}$ In 2014, in $A, B$, and $C,^{32}$ the CJEU also made it clear that

\footnotetext{
${ }^{27}$ http://ilga.org/downloads/03_ILGA_WorldMap_ENGLISH_Overview_May2016.pdf (access date 2 October 2017).

${ }^{28}$ See, for instance, vgl. 6 K 3802 / 13.A, VG Potsdam 13.05.2014; M 25 K 13.31348, VG München 19.11.2014. (Huebner, 2016, 256)

${ }^{29}$ For instance, Administrative Court Düsseldorf 14.1.2010 - 11 K 6778/09, Administrative Court Trier, 9.9.2010 - 1 L 928/10.TR (Algeria); Administrative Court Düsseldorf 14.1.2010 - 11 K 6778/09 (Morocco), Administrative Court Düsseldorf 27.8.2009 - 11 K 1003/09.A, Administrative Court Düsseldorf 11.3.2009 - 5 K 1875/08.A (Iran), Administrative Court Regensburg, 15.09.08 - RN 8 K 08.30020 (Algeria), Administrative Court Düsseldorf 21.02.08 - 11 K 2432/07.A (Egypt), Administrative Court Bremen, 28.04.06 - 7 K 632/05.A (Iraq) (Kalkmann, 2010, 26-29). Hempel (2014, 58) also mentions VG Aachen, U. v. $26.2 .2007 \pm 5$ K 2455/05.A.

${ }^{30}$ See, for instance, Administrative Court Frankfurt/Oder, 11. November 2010, VG 4 K 772/10.A; Administrative Court Chemnitz, 11. July 2008, A 2 K 304/06, Administrative Court Neustadt/Weinstraße, 8 September 2008, 3 K 753/07.NW, Munich/München, 30. Januar 2007, M 21 K 04.51404 (Kalkmann, 2010, 29).

${ }^{31}$ Letter from Bundesamt für Migration und Flüchtlinge, BAMF, to Member of Parliament Volker Beck, 27 December, 2012. Available: http://www.lsvd.de/fileadmin/pics/Dokumente/Recht/BAMF-121227.pdf).

32 Joined Cases C-148/13 to C-150/13, A, B and $C v$ Staatssecretaris van Veiligheid en Justitie, 2 December, 2014, ECLI:EU:C:2014:2406.
} 
decision-makers cannot rely on stereotypes 'alone' (for instance, questions about visiting gay bars and adopting certain looks or behaviour) and that late disclosure should not be a (sole) ground for refusal. Direct questions about sexual practices should not be asked and courts should not consider any tests, photographic or filmic evidence. ${ }^{33}$

Huebner (2016) notes progress since the two CJEU judgments with regard to discretion, although discretion has still occasionally been used in the courts ${ }^{34}$ and there are still examples of cases where the BAMF makes decisions as if the 2012 letter and the CJEU decision on $X, Y$ and $Z$ did not exist. ${ }^{35}$ While questions with regard to detailed sexual practices seem not to be asked anymore, other private details about past and present relationships, 'coming out', etc., still play a big role in assessing credibility (see Huebner 2016, 249).

\section{Intersectional legal challenges}

The asylum system asks PSASOGI for membership of a particular social group and therefore focuses on fixed social identities, but the focus on sexual identity is problematic as all too often the way PSASOGI live their SOGI is measured against white, Western notions of sexual identity, whereas other social categories impacting on that identity are not considered. In contrast to other areas of law, in asylum claims there is often not much evidence provided, and as Herlihy et al. (2010, p. 364) argue, 'decisions are inevitably based on assumptions about the content and quality of the information presented. These assumptions draw on subjective understandings of human interaction and behaviour.'

Studies on SOGI asylum claims have highlighted that decisions are often based on Western cultural expectations around sexuality that lack an understanding of the complexities of sexual identity (Morgan, 2006; O'Leary, 2008). As Morgan argues, such a racialised Western model of sexuality that seems to represent a stereotypical white male middle-class gay identity 'presumes clarity of boundaries between heterosexual and homosexual identity

\footnotetext{
${ }^{33}$ Whilst the judgement in $\mathrm{X}, \mathrm{Y}$ and $\mathrm{Z}$ is a positive step towards ending discrimination of SOGI claimants, as (Markard, 2014) points out, the judgement is still problematic as it leaves some leeway for (culturally specific) stereotypical behaviours. Also, as she points out, the court did not include the Advocate General's recommendation to give applicants sufficient opportunity to respond to doubts of his or her credibility (Markard, 2014).

${ }^{34}$ See, for instance, 5 K 534 / 13, VG Saarland 23.01.2015 (Huebner, 2016, 256).

${ }^{35}$ For instance, in a 2015 case the BAMF argued that a gay man who had been arrested and mistreated by police in Uganda, could go back and live discreetly, as sexual orientation itself was not criminalised but only certain sexual behaviour (see Huebner 2016, 255).
} 
and requires public expression of private and sexual behaviour' (Morgan, 2006, p. 151-152). In order to be successful, claimants need to conform to these Western stereotypes and a particular 'gay lifestyle', be 'out and proud', visit gay bars, and participate in lesbian and gay groups and at Gay Prides, for instance (Morgan, 2006; Bennett and Thomas, 2013). Western sexuality labels are not sufficient to capture PSASOGI's own diverse lived experience and the ways in which they understand and express their SOGI (Brotman and Ou Jin Lee, 2011). As Giametta (2014, p. 587) points out, the Western understanding of sexuality is often problematic for PSASOGI who 'negotiate their sexual and gender identities across cultural constructions of gender liminality and sexual identity that do not match the repertoires of western LGBTI identifications and lifestyles' (Giametta, 2014, p. 587).

In credibility assessments, this then becomes significant when claimants need to fit into these norms in order to be perceived as credible (Gartner, 2016). In general, the credibility of the SOGI claimants is often challenged because of implausibility, inconsistency or lack of detail (Huebner, 2016; Kalkmann, 2010). As Huebner (2016) argues, credibility assessments are based on collective heteronormative knowledge and essentialising nonheteronormative ways of life. This often includes ideas of a homogenous gay collective, and the devaluation and non-acceptance of bisexuality and fluid forms of sexuality. Sexual identity needs to be presented as something 'intrinsic' for a claim to be accepted. Decision makers use the binary framework of heterosexuality/homosexuality, which are defined as opposites and the 'real' sexualities. Asylum claims on grounds of bisexuality are therefore difficult to establish as it is assumed that the person can choose between heterosexuality and homosexuality. ${ }^{36}$ In addition, we can find court cases, where the belonging to the PSG was questioned because of the 'mere inclination' of homosexuality ${ }^{37}$ and where bisexuality was subsumed under homosexuality without any assessment of the risk of persecution as a bisexual person ${ }^{38}$. In such decisions, bisexuality and the risk of persecution on grounds of bisexuality are erased, contributing to the invisibility of bisexuality (Klesse, 2018; Monro, 2017).

Decision-makers rarely consider how sexuality intersects with gender, 'race', religion, age, and class for SOGI asylum claimants in ways that may differ from white, Western

\footnotetext{
${ }^{36}$ See, for instance, VG Saarland, 5 K 534/13, 18.02.2015; VG Ansbach AN 18 K 08.30201, 21 August 2008.

${ }^{37}$ See decision by Administrative Court of Ansbach AN 18 K 08.30201, 21 August 2008.

${ }^{38}$ See VG Saarland, 5 K 534/13, 18.02.2015; VG Ansbach AN 18 K 08.30201, 21 August 2008; Administrative Court of Augsburg Au 6 K 12.30387, 19.03.2013; Frankfurt am Main 1 L 3416/13. F. A, 26.09.2013;

Administrative Court of Potsdam, VG 6 K 338/17.A, 27. April 2017.
} 
middle-class gay men, for instance (Held 2016, 2017). ${ }^{39}$ For instance, owing to separating gender and sexuality, decision-makers often question the credibility of lesbian asylum claimants (Lewis, 2014). In the context of the US asylum system, Berger (2009) argues that the intersectionality of gender and sexuality needs to be incorporated into the law as the persecution on grounds of sexuality and gender are often linked (e.g. when lesbians end up in heterosexual relationships because of social pressures and experience domestic violence). Therefore, credibility needs to be tackled from an intersectional perspective (Lewis, 2014).

Hence, intersectional analysis could be productively used in SOGI asylum cases. As Markard argues with regard to the application of the Refugee Convention, 'courts do not always make use of the full potential of an intersectional analysis' (Markard, 2016, 59), but as she further explains:

Gender doesn't simply differentiate between "men" and "women", to the exclusion of inter* bodies and certain trans* and inter* identities. It is also fundamentally heteronormative, predetermining the acceptable sexual preference and the specific way in which to "do gender". [...] An intersectional approach can make these dimensions visible in a more differentiated manner. (Markard, 2016, p. 56)

Judgments based on the Convention PSG ground often focus on either sexuality or gender and leave out other Convention grounds, or do not consider intersections with these. Markard has also pointed out that the ways in which German courts engage with the PSG category (and the refugee definition in general) is problematic; often leading to the claimant being granted subsidiary protection rather than refugee status. As she argues: 'A careful consideration of the particular social group category with respect to age, gender and ethnicity as defining factors could lead to a more principled analysis and to recognition of refugee status rather than subsidiary protection.' (Markard, 2016, p. 56)

Not only gender and sexuality are linked in the lives of women (and men). As the Committee on the Elimination of Discrimination against Women (CEDAW) (Committee on the Elimination of Discrimination against Women, 2014, p. 2) has reiterated on several occasions:

\footnotetext{
${ }^{39}$ In my volunteer role at LISG, I saw many cases where claims were refused because it was not believed that the claimant was a 'genuine' lesbian. Claims were often challenged because of minor discrepancies in accounts, or because a delay in disclosure of sexual orientation, previous heterosexual relationships, having children, religious beliefs, and even older age were used to undermine the claimant's credibility.
} 
Discrimination against women based on sex and/or gender is often inextricably linked with and compounded by other factors that affect women, such as race, ethnicity, religion or belief, health, age, class, caste, being lesbian, bisexual or transgender and other status.

Hence, from a legal perspective, an intersectional approach is important for assessing the fear and the risk of persecution. As the next section will show, it is also important for understanding the social experiences of PSASOGI.

\section{Intersectional social challenges}

Almost 40 years ago, the Combahee River Collective (1982 [1978], 13), a Bostonbased, black, lesbian feminist group, stated in their 'Black feminist statement':

The most general statement of our politics at the present time would be that we are actively committed to struggling against racial, sexual, heterosexual, and class oppression and see as our particular task the development of integrated analysis and practice based upon the fact that the major systems of oppression are interlocking.

PSASOGI might face all of the structural oppressions addressed in this statement. Their experience is different from other SOGI minorities. Like other people from SOGI minorities, their experiences are shaped by the intersections of sexuality, gender, 'race', class, religion (and other social identifiers), but PSASOGI experience these intersections in complex ways through their persecution, escape and experiences with the asylum system. The particular context in which PSASOGI find themselves shapes the intersections of sexuality with other social categories in ways that are often not addressed in research on sexuality. Their experiences are shaped by something more than 'just' sexuality and 'race' and gender and class, namely by their 'refugeeness'.

We can see this in the ways that PSASOGI often do not find a 'safe haven' in Germany: their intersectional experience is shaped by a difficult asylum process and living conditions. ${ }^{40}$ Administrative staff is often not considerate towards the special needs of this

\footnotetext{
${ }^{40}$ http://lernen-aus-der-geschichte.de/International/content/12840 (access date 2 October 2017).
} 
group. For instance, being put in large accommodation centres ('Wohnheime'), where they have to share a room with other PSA and lack privacy, can be extremely difficult for PSASOGI. ${ }^{41}$ They can experience discrimination and verbal and physical violence not only from other asylum seekers, but also from security personnel, administrative staff and interpreters. ${ }^{42}$ SOGI claimants might end up in small villages, or in army camps in the woods (as one of the participants of the SOGICA project) and even if they are granted refugee status, they will have to stay in the district for a further three years. ${ }^{43}$ Specialised SOGI support is rarely available and there is also limited access to mental health support. Voluntary organisations are campaigning for the state to meet the increasing need for support of PSASOGI, for instance, by establishing safe residences for them, and a few accommodation centres solely for PSASOGI have opened recently. ${ }^{44}$

Whilst PSASOGI might experience homophobia (and sexism and racism) in the reception and accommodation centres, the general political climate in Germany affects their social experience too. The founding of the anti-Islam, far-right political movement PEGIDA $^{45}$ was a first sign of (renewed) anti-immigrant and racist sentiments in Germany (similarly to other European countries) (Adam, 2015; Czymara and Schmidt-Catran, 2016). For three years now, PEGIDA demonstrates weekly in Dresden (where only $1 \%$ of the population is Muslim), and has at times attracted up to 15.000 protesters. ${ }^{46}$ Several surveys

\footnotetext{
${ }^{41} \mathrm{http} / / /$ wafmag.org/2016/06/difficulties-lgbt-refugee-germany/ (access date 2 October 2017).

${ }^{42}$ http://learning-from-history.de/International/content/12840 (access date 2 October 2017).

${ }^{43}$ Claimants have no right to choose their place of residency. They can apply to be allocated to a particular town or district, but this is granted in only exceptional cases. There is no legal obligation (on state level) to house vulnerable persons separately and no systematic procedure exists. Asylum seekers stay in initial reception centres for up to six months before they move to accommodation centres or sometimes individual accommodation (applicants from 'safe countries' are required to stay at reception centres for the entire length of the asylum procedure, see AIDA, 2015, 10). Reception and accommodation centres are often (refurbished) former army barracks (sometimes situated in rural woods and cockroach infested (Scott, 2014)) and they are either managed by the responsible authorities themselves or by NGOs or private facility management companies. 'Security' at the reception centres is sub-contracted to private companies (usually the cheapest bidder). This is highly problematic, as some of these companies attract neo-Nazis and cases of racist abuse and violence of asylum seekers by these security guards are known, but not taken seriously by the state and are rarely punished (Komaromi, 2016).

${ }^{44}$ So far, two accommodation centres for SOGI asylum seekers have opened: one in Berlin that provides accommodation for 125 SOGI claimants and is managed by the Schwulenberatung Berlin, and one in Nuernberg that accommodates eight asylum seekers and is managed by the LGBT+ community organisation Fliederlich (both are paid for by the local authorities). Similar projects are planned in Cologne, Frankfurt and Munich. See, for instance, https://rainbow-refugees.cologne/ ; https://www.thelocal.de/20160223/berlin-opens-germanys-first-gay-refugee-centre; Iris Rajanayagam and Ahmed Awadalla, http://lernen-aus-der-geschichte.de/International/content/12840 (access date 2 October 2017).

${ }^{45}$ Patriotische Europaer gegen die Islamisierung des Abendlandes - Patriotic Europeans Against the Islamisation of the West.

${ }^{46}$ http://www.deutschlandfunk.de/pegida-demo-in-dresden-nicht-nur-raeumliche-naehe-zurafd.1773.de.html?dram:article_id=396185, access date 30 October 2017.
} 
indicate that anti-Islam resentments exist widely. ${ }^{47}$ One study suggests that whilst there is a general high acceptance of refugees, Muslim refugees are the least accepted (Czymara and Schmidt-Catran, 2016). Institutional racism also seems to be widespread in Germany. For instance, the far-right terrorist organisation National Socialist Underground (Nationalsozialistischer Untergrund) killed nine people with migrant backgrounds between 2000 and 2007 without serious police investigation (or if, then investigating in the victims' social circles), indicating an institutionalised blindness towards right-wing extremism (Adam, 2015). In 2015, there were 222 arson attacks on reception centres in Germany, but only four of these resulted in convictions (Komaromi, 2016, p. 80). ${ }^{48}$

These growing racist and Islamophobic sentiments have a specific impact on Muslim PSASOGI, who might find themselves in a complex web of homonationalist discourses. The term homonationalism describes processes 'where lesbian and gay tolerance is seen as a source of national pride and positioned against other seemingly less-tolerant nations'. Here, the 'liberal' Western gay subject is contrasted with the oppressed and/or homophobic nonWestern subject (Hubbard and Wilkinson, 2015, p. 605). The intersections of sexuality, 'race' and religion become visible here in the ways in which 'Muslim' and 'gay' are seen as incompatible identities, and the conflation of 'race' and religion leads to a discourse that constructs Islam as a homophobic religion (Haritaworn et al., 2008; Puar, 2007). In that respect, right-wing discourses often justify their Islamophobic sentiments with the argument that Islamic cultures apparently are intolerant towards SOGI minorities (Hubbard and Wilkinson, 2015). These discourses leave Muslim PSASOGI on contradictory terrain: fleeing because of homophobia and homophobic violence in their country of origin, they (as well as their supporters) often feel the need to represent their country of origin (as a whole) as homophobic during their asylum process; hence implicitly contributing to these homonationalist discourses. At the same time, some PSASOGI might be critical with the ways that authorities assume that these countries are homophobic (on a universal level). To balance the constructed dichotomy between the liberal, gay-friendly, 'civilised' West and the homophobic, 'backward' non-West, it is important to recognise firstly that most of the anti-

\footnotetext{
${ }^{47}$ For instance, $35 \%$ saying that migration from Islamic countries should be reduced, $44 \%$ disagreeing with the statement that 'Islam belongs to Germany', 57\% saying that they perceive Islam as a threat (Adam, 2015, p. 447)

${ }^{48}$ Hostility towards migrants and support for the AfD seems to be higher in East Germany. As Adam (2015) points out, likely reasons for the difference to West Germany is a higher unemployment rate, and a left-behind underclass (many young people moved to the West), lack of exposure to migrants but also a different political education. As he points out, the GDR did not have the same anti-racist education than in the West, where the Holocaust and German responsibility for World War II was part of re-education programmes introduced by the three Western allies, fostering a political consciousness and critical thinking of a new generation, whilst life in the GDR was determined by conformity and indoctrination.
} 
gay legislation in the 'non-West' was introduced by Western countries during times of colonialization, and secondly, that misogyny, sexism and homophobia are still widespread in Western countries too. The figure of the sexist and homophobic migrant has become more prevalent since the sexual assaults on New Year's Eve 2015-2016 in Cologne that were reportedly committed by men from North African and Middle Eastern countries and sparked a debate on integration. The construction of such a figure contributes to rendering a gay Muslim identity invisible.

\section{CONCLUSION}

This chapter has drawn mainly on literature and case law collected during the first phase of the SOGICA project. There is some evidence that differences exist in how the $28 \mathrm{EU}$ member states treat SOGI claims (Jansen and Spijkerboer, 2011). By focusing on Germany, Italy and the UK, SOGICA aims to contribute to harmonising the legal treatment of these claims, but also to improving PSASOGI's social experience. The chapter has begun to explore how intersectionality can be used methodologically, and how we might look at PSASOGI's legal and social experience from an intersectional perspective. I have discussed some of the ethical implications when doing research with PSASOGI and argued that the concept of 'vulnerability' is complex and also needs to be looked at from an intersectional angle. In the second phase of the project we will further discover how intersectionality plays out in the data collection and analysis; and what other ethical issues arise. We will also further explore what avenues exist for decision-making to not only focus on the PSG requirement but to also include other convention grounds; an approach that might be more useful than the current one. What is definitely needed, as I have argued in this chapter, is a shift in decision-making: from assessing belonging to a PSG solely with regard to sexual orientation and gender identity to assessing it as intrinsically linked to other social categories such as gender, age, 'race', religion and social class. This can be important for establishing credibility as well as risk of persecution. Sexual and gender identities are more complex than the Western stereotypes of white middle-class gay men. As the asylum system draws on fixed versions of these identities that do not allow any fluidity, claims on grounds of bisexuality are difficult to establish (and it is therefore not surprising that so far we have not found any participants who have claimed asylum on these grounds). 
There is some indication that SOGI claims are increasingly rejected on grounds of 'asylum relevance' (i.e. that risk of persecution is assessed as low) and that the 'discretion argument' is also frequently used again in Germany. Our project will further explore how the changing political climate (more to the right) and homonational discourses affect SOGI asylum policies and decision-making and PSASOGI's legal and social experiences. It will also further explore how these experiences are shaped by the intersections of sexuality, gender (identity), religion, 'race', ability, age and social class; which has only been touched upon in this chapter.

\section{REFERENCES}

Adam, Heribert (2015): "Xenophobia, Asylum Seekers, and Immigration Policies in Germany." In: Nationalism and Ethnic Politics 21, pp. 446-464.

AIDA, Asylum Information Database, 2015. Country Report: Germany. AIDA.

Baillot, Helen/Cowan, Sharon/Munro, Vanessa E. (2012): "Hearing the Right Gaps: Enabling and Responding to

Disclosures of Sexual Violence within the UK Asylum Process." In: Social \& Legal Studies 21/3, pp. 269-296.

Bennett, Claire/Thomas, Felicity (2013): "Seeking Asylum in the UK: Lesbian Perspectives." In: Forced Migration

Review 42, pp. 25-28.

Berger, Susan A. (2009): "Production and Reproduction of Gender and Sexuality in Legal Discourses of Asylum in the

United States." In: Signs 34/3, pp. 659-685.

Bhimji, Fazila (2016): "Visibilities and the Politics of Space: Refugee Activism in Berlin." In: Journal of Immigrant \& Refugee Studies 14, pp. 432-450.

Clark-Kazak, Christina (2017): "Ethical Considerations: Research with People in Situations of Forced Migration." In: Refuge - Canada’s Journal on Refugees 33, pp. 11-17.

Cochrane, Clare (2015): Sharing Knowledge; Sharing Power - what we learned. CSEL. http://csel.org.uk/assets/images/resources/SKSP-event-short-report.pdf 
Combahee River Collective (1982): “A Black Feminist Statement”. In Akasha Gloria Hull/Barbara Smith/Patricia Bell-

Scott (eds.): All The Women Are White, All The Blacks Are Men, But Some Of Us Are Brave - Black Women's Studies, New York: The Feminist Press, pp. 13-22.

Committee on the Elimination of Discrimination against Women (2014): General recommendation No. 32 on the gender-related dimensions of refugee status, asylum, nationality and statelessness of women (CEDAW/C/GC/32) [WWW Document]. URL https://documents-ddsny.un.org/doc/UNDOC/GEN/N14/627/90/PDF/N1462790.pdf (accessed 30.03.17).

Czymara, Christian S./Schmidt-Catran, Alexander W. (2016): "Wer ist in Deutschland willkommen?: Eine Vignettenanalyse zur Akzeptanz von Einwanderern." In: KZfSS Kölner Zeitschrift für Soziologie und Sozialpsychologie 68, pp.193-227.

Epstein, Steven/Carrillo, Hector (2014): "Immigrant sexual citizenship: intersectional templates among Mexican gay

immigrants to the USA." In: Citizenship Studies 18/3-4, pp. 259-276.

Firth, Georgina/Mauthe, Barbara (2013): "Refugee Law, Gender and the Concept of Personhood." In: International Journal of Refugee Law 25, pp. 470-501.

Gartner, Johannes Lukas (2016): (In)credibly Queer: Sexuality-based Asylum in the European Union [WWW Document]. Verfügbar unter http://www.humanityinaction.org/knowledgebase/578-in-credibly-queer-sexualitybased-asylum-in-the-european-union/print (Zugriff am 7.11.16).

Giametta, Calogero (2014): "'Rescued' subjects: The question of religiosity for nonheteronormative asylum seekers in

the UK." In: Sexualities 17/5-6, pp. 583-599.

Hathaway, James C /Foster, Michelle (2014): The Law of Refugee Status (2 ${ }^{\text {nd }}$ ed.), Cambridge: Cambridge University

Press.

Haritaworn, Jin/Tauqir, Tamsila/Erdem, Esra (2008): "Gay Imperialism: Gender and Sexuality Discourse in the 'War of

Terror'." In: Adi Kuntsman/ Esperanza Miyake (eds.), Out of Place: Interrogating Silences in Queerness/ Raciality, York: Raw Nerve Books, pp.71-95.

Harrell-Bond, Barbara/Voutira, Eftihia (2007): "In Search of 'Invisible' Actors: Barriers to Access in Refugee Research." In: Journal of Refugee Studies 20, pp. 281-298. 
Held, Nina (2017): What does a genuine lesbian/gay relationship look like in the eyes of asylum decision makers?

Discover Society. Verfügbar unter https://discoversociety.org/2017/05/02/what-doesa-genuine-lesbiangay-relationship-look-like-in-the-eyes-of-asylum-decision-makers/ (Zugriff am 15.09.17).

Held, Nina (2016): "What does a 'genuine lesbian' look like? Intersections of sexuality and 'race' in Manchester's Gay

Village and in the UK asylum system." In: Francesca Stella/Yvette Taylor/Tracey Reynolds/Antoine Rogers (eds.), Sexuality, citizenship and belonging: trans-national and intersectional perspectives. Routledge advances in critical diversities 1, London: Routledge, pp. 131-148.

Hempel, Jessica Johanna (2014): Sexuelle Orientierung als Asylgrund - Entwicklungen der europäischen

Asylrechtspraxis am Beispiel Deutschlands. Diplomarbeit Universität Wien.

Herlihy, Jane/Gleeson, Kate/Turner, Stuart (2010): What Assumptions about Human Behaviour Underlie Asylum Judgments? In: International Journal of Refugee Law 22, pp. 351-366.

Hubbard Phil/Wilkinson Eleanor (2015): "Welcoming the World? Hospitality, Homonationalism, and the London 2012

Olympics." In: Antipode 47/3, pp. 598-615.

Hübner, Katharina (2016): "Fluchtgrund sexuelle Orientierung und Geschlechtsidentität:

Auswirkungen von heteronormativem Wissen auf die Asylverfahren LGBTIGeflüchteter." In: Feministische Studien 34/2, pp. 242-260.

Jansen, Sabine/Spijkerboer, Thomas (2011): Fleeing Homophobia: Asylum Claims Related to Sexual Orientation and Gender Identity in Europe, Amsterdam: Vrije Universiteit Amsterdam.

Kalkmann, Michael (2010): "Questionnaire European Research Project, Fleeing Homophobia,

Seeking Safety in Europe, Best practices on the (legal) position of LGBT Asylum Seekers in the EU Members States". Verfügbar unter https://www.coc.nl/wpcontent/uploads/2013/11/Fleeing-Homophobia-report-EN_tcm22-232205.pdf.

(Zugriff am 20.06.2018).

Klesse, Christian (2018, forthcoming): "On the Government of Bisexual Bodies. Asylum Case Law and the Biopolitics 
of Bisexual Erasure." In: H Richter (ed.), The Body of the Governed: Race and Gender in the Era of Biopolitical Governance, Lanham: Rowman and Littlefield.

Komaromi, Priska. (2016): "Germany: neo-Nazis and the market in asylum reception." In: Race \& Class 58, pp. 79-86.

Krause, Ulrike (2017): "Researching forced migration: critical reflections on research ethics during fieldwork." In: RSC Working Paper Series 123.

Lee, Edward Ou Jin./Brotman, Shari (2011): "Identity, Refugeeness, Belonging: Experiences of Sexual Minority

Refugees in Canada." In: Canadian Review of Sociology 48/3, pp. 241-274.

Lewis, Rachel A. (2014): "Gay? Prove it": The politics of queer anti-deportation activism." In: Sexualities 17/8, pp.

958-975.

Mackenzie, Catriona/McDowell, Christopher/Pittaway, Eeileen (2007): "Beyond 'Do No Harm': The Challenge of Constructing Ethical Relationships in Refugee Research". In: Refugee Studies 20, pp. 299-319.

Markard, Nora (2016): "Persecution for reasons of Membership of a Particular Social Group: Intersectionality avant la

lettre?" In: Sociologia del Diritto, Sonderheft „Intersectionality, Law and Society“.

Markard, Nora (2015): "Wer gilt als Flüchtling — und wer nicht? Rechtliche Grundlagen". In: Sozial Extra 39, pp. 24-27.

Markard, Nora (2014): CJEU ends degrading questioning of homosexual [WWW Document]. Verfügbar unter http://curia.europa.eu/juris/document/document.jsf?docid=160244\&mode=req \&pageI ndex $=1 \&$ dir $=\& o c c=$ first $\&$ part=1\&text=\&doclang=EN\&cid=91836 (Zugriff am 18.12.16).

Markard, Nora (2013): "EuGH zur sexuellen Orientierung als Fluchtgrund: Zur Entscheidung „X, Y und Z gegen Minister vor Immigratie en Asiel “vom 7.11. 2013." In: Asylmagazin, pp. 402-408. Verfügbar unter: www. asyl. net/leadmin/user_upload/beitraege__ asylmagazin/Beitraege_AM_2013/AM201312_beitragmarkard. pdf. (Zugriff am 20.06.2018).

Markard, Nora (2011): "Review. Reviewed Work(s): Internationale Normen und das Rechtssystem: Der Umgang mit geschlechtsspezifisch Verfolgten in Großbritannien und Deutschland by Heike Brabandt." In: Kritische Justiz 44/4, pp. 471-473. 
Matsuda, Mari J. (1991): "Beside My Sister, Facing the Enemy: Legal Theory out of Coalition." In: Stanford Law Review 43, pp. 1183-1192.

McConville, Mike/Chui, Wing Hong (Eds.) (2007): Research Methods for Law, Edinburgh: Edinburgh University Press.

Monro, Surya/Hines, Sally/Osborne, Antony (2017): "Is bisexuality invisible? A review of sexualities scholarship

1970-2015." In: The Sociological Review, pp. 1 -19.

Morgan, Deborah A. (2006): "Not Gay Enough for the Government: Racial and Sexual Stereotypes in Sexual Orientation

Asylum Cases." In: Law \& Sexuality: A Review of Lesbian, Gay, Bisexual, and Transgender Legal Issues 15, pp. 135-162.

O'Leary, Barry (2008): "We Cannot Claim Any Particular Knowledge of the Ways of Homosexuals, Still Less of Iranian

Homosexuals ...": The Particular Problems Facing Those Who Seek Asylum on the Basis of Their Sexual Identity." In: Feminist Legal Studies 16/1, pp. 87-95.

Puar, Jasbir K. (2007): Terrorist Assemblages: homonationalism in queer times, Durham and London: Duke University

Press.

Rapley, Tim (2007): "Interviews." In: Clive Seale/Giampietro Gobo/Jaber F. Gubrium/David Silverman (Eds.), Qualitative Research Practice, London et al.:Sage, Chapter 1.

Scott, Penelope (2014): "Black African asylum seekers' experiences of health care access in an eastern German state." In: International Journal of Migration, Health and Social Care 10, pp. 134-147.

Stevenson, Jacqueline/Willott, John (2006): Cultural influences in data collection and analysis: issues in conducting research with refugees. Leeds Metropolitan University.

Tometten, Christoph (2016): Nur fragmentarischer Schutz: Asyl wegen sexueller Orientierung und Geschlechtsidentität. Verfassungsblog.

United Nations High Commissioner for Refugees (2003): "The issue of "trust" or "mistrust" in research with refugees: choices, caveats and considerations for researchers, Tricia Hynes [WWW Document]." UNHCR. Verfügbar unter: http://www.unhcr.org/research/working/3fcb5cee1/issue-trust-mistrust-researchrefugees-choices-caveats-considerations-researchers.html (Zugriff am 3.4.17).

Venturi, Denise (2017): "Reflections on empirical research with LGBTI refugees - a legal scholar's perspective." In: Oxford Monitor of Forced Migration 6, pp.20-23. 
Wessels, Janna (2017): "Publicly Manifested—Fatefully Determined—Invariably "Discreet": The Assessment of Sexuality-Based Asylum Claims in Germany and France.” In: Canadian Journal of Women and the Law 29/2, pp. 343-374. 